\title{
Assessing Petiole Iron Content in Fitis vinifera 'Chardonnay' Using
Rellectance Based Hyperspectral Indices
}

\author{
C. Gomzalez-Flor, G. Gorchs and L. Serrano

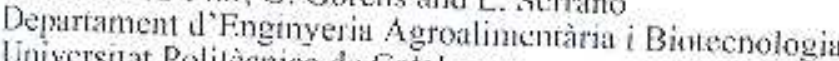 \\ Universtat Polilecuica de Catalunys \\ Barcelona \\ Spain
}

Kaywords: iron chlorosis, clilorophyll indices, pelisle analyxis, precisiun viticulture,
canopy, vines

\begin{abstract}
Iron chloroxis is a relewant mutritional disorder in vineyards grown in the Mediterranean area, which affects luth berry yield and quality. Reflectance based remote sensing fechniques might provide a valuable fool to characterize iron chlornsis incidence through the assessment of chlorophyll content. The study was combucted in ten vincyards (Vilis vinifera 'Chardonnay') to test the capability of reflectance based chlorophyll indices at assessing petible iron content. Significant relationships emerged between petiole $\mathrm{Fe}$ concentration and reflectance based Difference 705 (m). Among the chlorophyll indices tested, the modified Nermalized

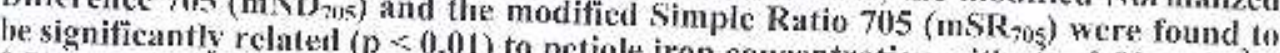
0.72 , respectively, In addition the petiole iron concentration with $r^{2}=0.82$ and $r^{2}=$ also significantly related to petiol Chiorophyll Normalized Difference Index was $=0.53, p<0.05)$. The results ubtained concentration although in a lesver extent $\left(r^{2}\right.$ derived from canopy reflectance suggest that narrow-band chlorophyll indices concentration in 'Chardonna' vincyards.
\end{abstract}

\section{INTRODUCTION}

Iron charosis is a nutritional disorder that affects a wide range of crops in semiarid enviromments like the Mediterrancan regun, Since irtm is a constituent of chlorophyl thylacoid membranes, its deficiency aflects photosynthesis processes fTerry and Abadia. 1986). Patticularly, in vineyards. Fis deficiency has been reported ur decrease plant vigour while affecling yield and berry compositiun (Liaz et al, 2010: Martín et al., 2007). In general, imn chlorosis leads ta a decrease of must sugar content while total acidity increases or docs not vary (Mlartin et al, 2007 ).

Traditional methods for assessing iron chlorasis, as blades or petiole analysis, are destruclive, time consuming and ofter inaceurate (i.c. liniled number of samples). Alternalively, and because $F$ : deficienty finally results in an inhibition of chlonphyll synthesis, optical methods riight be a valuable lool for early detection of iron chlorosis occurrence while being a rapid and non destructive technique. Atumpts to eximate petislt le concintration using optical methods such as the SPAD chlorophyll meter (i.e. absurbance in the red and infrared regions) have repirks poor correlation botween contrast, recent studies and petiole fe eoncentration (I) a az et al, 2009, 2010). In based chlormphyll indices at diffir vineyards have shown the feasibility of reflectance indticed charosis (Zareo-l cjada ot scaks (from kuf to landscape) to assess ironHowever, to our kmuledge, rufled al, 2005; Martin el al, 2007; Gil-Pérez el al., 2010). agamst masurements of petiols inomed based chloruphyll indicus have nut been tested

ron concentration.

chlorophyll indices at as this study was to test the suitability of reflectance based at the canoy level. 


\section{VATERIAL AND MEIHODS}

The study took place in ten conmercial vineyards cultivated with Vitis vinifera $\mathrm{L}$. Chardtumay". Plots were located in Alt Penedès region (Burculona. Spain). Average annual kmperalures (1998-2007) range from 13.7 to $15.8{ }^{\circ} \mathrm{C}$ while cumulative annual precipialion rumges from 266.2 to $612.6 \mathrm{~mm}$.

Vincyard planting characteristics are summarized in Serrano cl al. (2012). Spectral data were collecket at veraisen $(16-22$ July 2007$)$ on three vines per vincyand using a narrow-bandwidth spcetroradiumele (LNISPEC, PP Systems Ltd. Havervill MA. LSA) using a 12 field of view lorsopstics (UNI-710. PP Systems Ltd., ILavervill MA. ISA) positioned $0.75 \mathrm{~m}$ above the canopy and oricnted to the vine. Itradiance was moasured using a cosine cortected lens (UVI-685, PP Systems. Lid., Havervill MA, USA) oriented to the sky. Several reflectance chlorophyll indicss were derived from apparent reflectance as reported in Table 1.

Petiole iron concentration ( $1 \mathrm{e}_{\mathrm{p}}$ ) was determined in July 2007 . A hundred petioles werc randumly selected within each vineyard. The $\mathrm{Fc}_{\mathrm{p}}$ was determined by specl.rophokumetry (PerkinElmer 4300 DV ICPOCLS, PerkinFlmkr, Massachussets, USA), after peliole wel digestion with $\mathrm{HNO}_{3}$ and $\mathrm{H}_{2} \mathrm{O}_{2}$.

Analysis of variance and correlation were executed using the statistical packages SPSS 17.0 and SPSS 19.0 (SPSS Jnc. Chicago ILL, USA). Vineyard was unsidered as a source of variation in AVOVA analyses. Means were compared using the Tukey's test and correlation analyses were used $u$ study the relationshyps berween spectral indicus and petiole iron concentration.

\section{RESULTS AND DISCLISSION}

Petiole iron concentration (Fe, ramest between 31 and $66 \mathrm{mg} / \mathrm{kg}$ which is considered as medium and above medium content (Cahния, 1985). Nonetheless, in our study, $\mathrm{FL}_{\mathrm{p}}$ was slightly lower than that reported in previous studies conducted on vinsyards grown on calcareous soils without fertilizer applicalion (Díazet al., 2010).

As iron is a constituent of the chloroplasts thylacoid membane, iron chlorosis might be assessod theugh changes in chlorophyll content (Mlarlín cl al.. 2007). Previous studies have tested the vapability of spectral indices at estimating varialium in chlorophyll content and conceniration in several species (Sims and Gamon, 2002; 1.cMaric et al., 2004; Serrano, 2008), including sludies conducted in vineyatds (Steele el a1., 2008, Martin et al., 2007; Gil-P'rez ct al., 2010). Huwever, in these studies, chlorophyll spectral indices were found to be poorly relalcd tu lissue Fe concentration. In contrast. in vur study, chlorophyll spectral indices provided conliskent estimates of ficp concentration. Indeed, among the indices tested. Fe, was louml to be closely related to mSR nos ansi IIND $05\left(R^{2} \quad 0.72, R^{2}-0.82 ; P<0.01\right.$ : respcctively) and in a lesser extend to (CI NDI $\left(R^{2}-0.53 ; P<0.05\right)$ (Fig, 1).

The lack of correlation between tissue $\mathrm{Fe}$ ismcentration and chlorophy]. concenlration is altributed to a phenomenon known as iron chlorosis paradox (13avaresco el al., 1999), which describes plants that present chlorotic: kaves with high Fe concentration as a resulf of severe growth inhibition. Thus, the close corrclatiun between chlorophyll spectral indices and $\mathrm{Fe}_{\mathrm{p}}$ found in our study might be aturihuted to the low incidence of iron delicisncy su that, reduction in vine growth was probably mintr.

Previous studics have divumented a close relationship berween chlorsphyll and leaf blade le concentration (Terry and Abadia, 1987) as well as between mineral composition in both blade and putiole tissuex (Bavaresco et al., 1997). Therefore, the capability of chlorophyll spectral indices to Irack Fe, suggests that, under the conditions of our study, variation in leaf chlorophyll conkent was largely associated to changes in pectible iron concentration,

In conelusion, in our study, chlorophyll indices derived from spectral reflectance successfully estimated petiole iron concentration. Howswer, duc to the low incidence of iron chkrosis fisund in our study, chatacterization of the rstalionships between reflectance based chlomphyll indices with respect to variations in $\mathrm{Fe}$, over a wide range of chlorosis 
occurrence is needed. More sudic, partisularly at larger scales, are necessary in order to confirm the capability uf llk: reflcotance based chlorophyll indices at assessing $\mathrm{Fe}_{\mathrm{p}}$ concentration.

\section{CONCLCSIONS}

Our sludy shuws the reliability of three chlorophyll indices, mSR an, nND;is and ChI NDI, derived from reflectance measurements at the canopy level Lo aswes, putiole: iron concentration in field grown vincyards. More studies are needed to samlim the results bhained by considering a wider range of iron-inducud chlirasis oweurrence and cultivars.

\section{ACKNOWLEDCEVMENS}

We thank Dr. Ramon Josa for his advies in the field sampling and lab analysis assistance, We also thank wo Coulentiu S.I.. and, particularly Mr. Antoni Abad, for providing us petiole analysis datu.

\section{Literature Cited}

Bavaresco, L. 1097. Relationship between chlorosis occurrence and mineral compusilion of grupevine leases and berries. Communications in Soil Science und Plant Analysis $28: 13-21$.

Bavarcses, I.., Giachino, L. and Colla, R, 1999). Iron chlorosis paradex in mrapevine, I. Plant Nutrition 22:1584-1547.

Gahom, G.A. 198\%. 1etilizing Fruit Crops. Bulletin 458. The Ohio State University, Ohio.

Diaz, 1., del Campillo, M.C., Cantos, M. and Torrtnl, I, 2009. Iron deficiency symptoms in grapevine as affected by the irm oxide and carbonate contents of model substrates. Plant and Soil $322: 293-302$.

Diaz, L., del Campillo, M.C., Barrin, V and Torrent. J. 2010. Predicting the occurrence of iron chlorosis in grapevine with tests based on soil iron forms. J. Intl. Sci. Vigne Vin. $44: 77-85$.

Gil-Péres, B., Zurco-Tejada, P.J., Cortea-Gumaraes, A.. Relea-Gungas, F., NavasGracia, 1..... Hernández-Aavarro, S., Sanz-Requena, J.F. Berjü, A. and Martin-Gil, I. 2010 . Rimote sensing detection of nutrient uptake in vimeyards using narrow-band hyperspectral imagery. Vitis 49:167-173.

le Vaire, $G$., 1 tancois, $C$, and Dufrene, E. 2004. Towards universal broad leaf chlorophyll indices using PROSPECT simulalud datubase and hyperspectral reflectance measutements. Remote Sensing of Envirument 89:1-28.

Martin. P., Zarco-Tejada. P. Gumzale, M. and Berjon, A. 2007. Using hyperspectral remote sensing to map graje yuality in 'Tempranillo' vineyards affected by iron deticiency chlousis. Vilis. 46:7-14

Serrano, L. 2008. Fffects of leal structure on reflectance estimates of chlorophyll cuntent. International Journal of Remote Sensing. 24:5265-5274.

Serano, $1 \ldots$, Gunzález-Flor, $C$ and Gorchs, G. 2012. Assessment ur erapu yick and cumpusilion nsing the reflectance based Water Index in Mludictrancan rainfed vincyards. Remote Sensing of linvironment 118:249-258.

Sims, $D$. and Gamon, J. 2002. Relationships between leaf pigntent content and spectral reflectance across a wide range of species, leal' structures and dkvckipmental stages. Remote Sensing ol Linvironment $81: 337-254$.

Steele, M., (ittelson, A. and Rumdquist, D. 2008 . Nondestructive esrimation of leaf chlorophyll content in grapes. Amer. I. Fnology Viticulture $59: 299-305$.

Terry, $V$, and $A$ badia, .I. 1986 . Funclion of iron in chloroplasts. Journal of Plant Nutrition 9:609-646.

Zarco-Tejada, P., Berjin, A.. I.opez-Lozano, R., Miller, I., Martin. P.. Cachorro. V.. Gonzalez, M. and Frulos, A. 2005 . Assessing vineyard condition with hyperspectral indices: leal and caropy reflectance simulation in a row-structured discontinuous camply. Rentste Stmsing of Linvironment $99 ; 271-287$. 


\section{Talules}

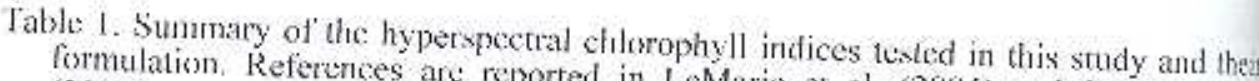
(20008).

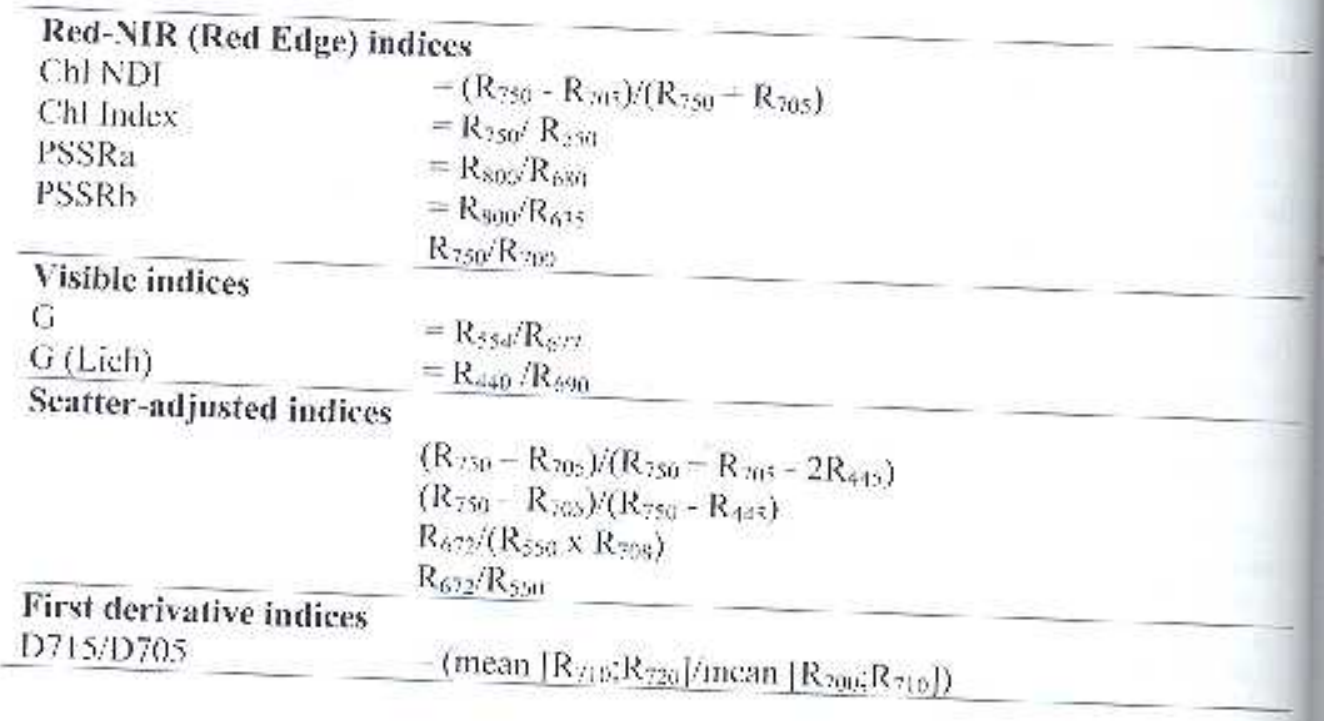




\section{ligures}

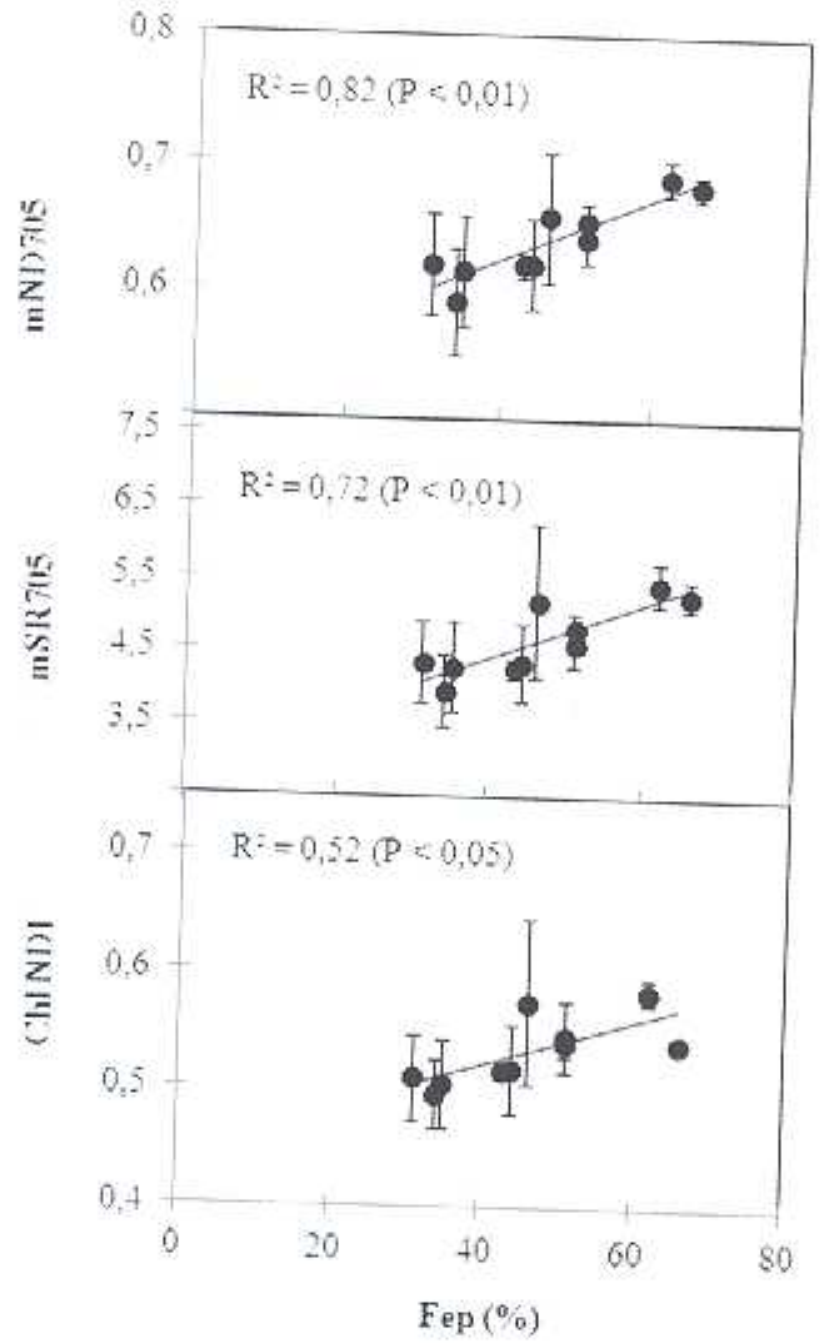

Fig 1. Relationships between petisk lic content ( $\mathrm{fe}_{\mathrm{p}}$ ) and the Chlorophyll Nomalized Dillerence Index (Chl NDI), Modified Simple Ratio 705 (onSR Nurmalized Difference 705 (mVD) intasurements ( $n=10)$. 